\title{
DETERMINANTY ZMIAN DEFICYTU BUDŻETU PAŃSTWA I DŁUGU PUBLICZNEGO W PAŃSTWACH UNII EUROPEJSKIEJ W 2010 ROKU
}

\section{Wprowadzenie}

Opracowanie stanowi kontynuację analizy stanu finansów publicznych krajów Unii Europejskiej w okresie od 2008 roku (czyli od roku wybuchu globalnego kryzysu finansowo-gospodarczego), którą rozpoczęto w artykule Wpływ światowego kryzysu ekonomicznego lat 2008-2009 na poziom deficytu budżetowego i długu publicznego w krajach Europy Srodkowej $i$ Wschodniej na tle pozostałych krajów UE. ${ }^{1}$ W latach 2008-2009 w krajach Unii Europejskiej mieliśmy do czynienia z powszechnym wzrostem deficytu budżetu państwa oraz powszechnym wzrostem długu publicznego. Wielu polityków gospodarczych oraz ekonomistów tłumaczyło pogarszanie się stanu finansów publicznych w tak wielu państwach światowym kryzysem gospodarczym, a zwłaszcza jego najważniejszym elementem, czyli recesją gospodarczą, która dotknęła te państwa. We wspomnianym opracowaniu podjęto próbę identyfikacji rzeczywistych przyczyn wzrostu deficytu budżetowego i w konsekwencji wzrostu długu publicznego w krajach należących do Unii Europejskiej. Zasadniczym celem tej analizy była odpowiedź na pytanie, w jakim stopniu za pogorszenie się wyniku budżetu państwa odpowiadał spadek realnego PKB, a w jakim stopniu należało go tłumaczyć bieżącą polityką budżetową. $\mathrm{W}$ prezentowanym opracowaniu analizie poddana zostanie zmienność deficytu budżetowego i zmienność długu publicznego w krajach UE w 2010 roku.

Należy przypomnieć, że aby prawidłowo ocenić stan finansów publicznych w danym kraju, analizie należy poddać budżet państwa rozumiany jako cały sektor finansów publicznych. Miernikiem rzeczywistego stanu budżetu państwa w danym roku jest wynik ekonomiczny budżetu państwa (wyrażony w PKB w cenach rynkowych), a nie wynik kasowy, co szczegółowo wyjaśniono we wspomnianym

1 Opracowanie to zostało opublikowane w: Polityka gospodarcza $w$ warunkach deficytu budżetowego i długu publicznego, red. M. Krawczyk, D. Malinowski, Centrum Doradztwa i Ekspertyz Gospodarczych SGH, Warszawa 2011. 
opracowaniu. W opracowaniu tym przedstawiono też autorską koncepcję formuły wyniku ekonomicznego budżetu państwa. Formuła ta ma postać:

WYNIK EKONOMICZNY BUDŻETU PAŃSTWA $(t)$

$=[D K(t)-\mathrm{A}(\mathrm{t})+\Delta$ NALEŻNOŚCI PAŃSTWA $(\mathrm{t})]$

$-\left[\mathrm{WK}(\mathrm{t})+\mathrm{B}(\mathrm{t})+\Delta\right.$ ZOBOWIĄZAŃ WYMAGALNYCH PAŃSTWA $\left.(\mathrm{t})^{2}\right]$

gdzie:

DK (t) - oficjalne dochody kasowe budżetu państwa w roku t, WK $(\mathrm{t})$ - oficjalne wydatki kasowe budżetu państwa w roku $\mathrm{t}$,

A ( $(t)$ - te dochody zaliczane do oficjalnych dochodów kasowych, które w rzeczywistości nie pomniejszają oszczędności, jakie musi w okresie t pozyskać państwo na finansowanie bieżącego deficytu budżetowego,

B (t) - wypływy środków publicznych dokonane w roku t, które mają charakter wydatków kasowych, ale nie zostały w roku t zaliczone do wydatków kasowych; składnik B formuły jest zatem miarą skali tzw. zamiatania deficytu pod dywan w roku t.

W praktyce w formule tej można pominąć zmianę należności państwa. Pozycja ta de facto sztucznie zawyża wynik ekonomiczny budżetu państwa. Na ogół bowiem znaczna część należności państwa (należności te pochodzą głównie z tytułu zaległości podatkowych) nigdy nie jest odzyskiwana.

Inna sytuacja ma miejsce $\mathrm{w}$ przypadku przyrostu zobowiązań wymagalnych państwa. Zobowiązania te państwo musi uregulować w przyszłych okresach, a więc w przyszłych okresach pozyskać oszczędności na ich sfinansowanie. Jak wspomniano wcześniej ujęcie ekonomiczne wyniku budżetu państwa tym m.in. różni się od ujęcia kasowego tego wyniku, że traktuje przyrost zobowiązań wymagalnych państwa identycznie jak wydatek kasowy. Mimo że ta część przyrostu długu publicznego, która jest kreowana przez przyrost zobowiązań wymagalnych państwa, będzie finansowana w przyszłych okresach, to ekonomicznie związana jest z okresem bieżącym (rokiem dla którego wyznaczamy wynik budżetu państwa). Zmiana zobowiązań wymagalnych państwa w roku t wpływa bowiem w okresie bieżącym (podobnie jak wzrost wydatków kasowych państwa) na kształtowanie takich kategorii, jak wielkość popytu globalnego, stopa inflacji, saldo bilansu obrotów bieżących z zagranicą, przeciętna rynkowa stopa procentowa.

\footnotetext{
2 Chodzi o przyrost zobowiązań wymagalnych państwa z tytułu niezapłacenia za otrzymane produkty oraz z tytułu niezrealizowania wydatków transferowych, których realizacja ciążyła na państwie.
} 
Ostatecznie zatem nowa formuła wyniku ekonomicznego budżetu państwa ma postać:

WYNIK EKONOMICZNY BUDŻETU PAŃSTWA $(\mathrm{t})=[\mathrm{DK}(\mathrm{t})-\mathrm{A}(\mathrm{t})]$ $-[W K(t)+B(t)+\Delta$ ZOBOWIĄZAŃ WYMAGALNYCH PAŃSTWA $(\mathrm{t})]$

Dopiero tak wyznaczony wynik ekonomiczny budżetu państwa pokazuje rzeczywisty stan budżetu państwa w roku t, tzn. informuje o faktycznej zmianie długu publicznego, jaka nastąpiła w roku t. Można zatem zapisać:

WYNIK EKONOMICZNY BUDŻETU PAŃSTWA $(\mathbf{t})=\Delta$ DŁUG PUBLICZNY $(\mathrm{t})$

Zmianę długu publicznego w roku t można podzielić na dwie części:

a) $[\mathrm{DK}(\mathrm{t})-\mathrm{A}(\mathrm{t})]-[\mathrm{WK}(\mathrm{t})+\mathrm{B}(\mathrm{t})]$

Jest to ta część przyrostu długu publicznego w roku t, którą trzeba sfinansować w okresie bieżącym, czyli w roku t, tzn. jest to ilość oszczędności, jakie w roku t musi pozyskać państwo na finansowanie bieżącego deficytu budżetowego.

b) $\triangle$ ZOBOWIĄZAŃ WYMAGALNYCH PAŃSTWA (t)

Jest to ta część przyrostu długu publicznego w roku t, która nie wymaga finansowania w okresie bieżącym (a więc absorpcji oszczędności w roku t). Na pokrycie tej części przyrostu długu publicznego w roku t państwo będzie musiało jednak wykorzystać część oszczędności wygenerowanych przez daną gospodarkę lub nabytych za granicą w przyszłych okresach. Uwzględniając tę część przyrostu długu publicznego, wynik ekonomiczny budżetu państwa pokazuje całkowite (tzn. występujące w okresie bieżącym oraz w okresach przyszłych) skutki stanu budżetu państwa w danym roku - m.in. pokazuje właśnie jakie łączne (w okresie bieżącym i okresach przyszłych) zapotrzebowanie na oszczędności generuje działalność państwa w danym roku.

Prezentowane w opracowaniu wyniki ekonomiczne budżetu państwa analizowanych państw są policzone zgodnie z powyższą formułą wyniku ekonomicznego. Wyznaczono je na bazie danych Eurostatu.

Zanim przejdziemy do analizy stanu finansów publicznych krajów UE w 2011 roku, należy przypomnieć wnioski płynące z analizy okresu 2008-2009.

Pierwszy wniosek, jaki płynie z prowadzonej analizy, jest taki, że w pozostałych krajach UE w latach 2008-2009 średnia skala pogorszenia się wyniku ekonomicznego była większa niż w krajach Europy Środkowej i Wschodniej. W krajach Europy Środkowej i Wschodniej w badanym okresie wynik ekonomiczny budżetu państwa jako \% PKB pogorszył się średnio o 5,05 pkt. proc., a w pozostałych krajach UE o 6,62 pkt. proc. 
Drugi wniosek jest taki, że w większości pozostałych krajów UE, podobnie jak w większości krajów Europy Środkowej i Wschodniej, jedyną bądź główną przyczyną pogorszenia się wyniku ekonomicznego budżetu państwa jako \% PKB w latach 2008-2009 był wzrost wydatków budżetowych wyrażonych w \% PKB.

Trzeci wniosek brzmi: w pozostałych krajach UE wzrost udziału wydatków budżetowych w PKB, podobnie jak w krajach Europy Środkowej i Wschodniej, był przede wszystkim spowodowany wysoką dynamiką wzrostu nominalnych wydatków budżetowych. W pozostałych krajach UE, podobnie jak w krajach Europy Środkowej i Wschodniej, za pogorszenie się wyniku ekonomicznego budżetu państwa jako \% PKB w latach 2008-2009 odpowiadała głównie bieżąca polityka budżetowa, a nie recesja gospodarcza. Trzeba jednak dodać, że rola recesji gospodarczej w pogarszaniu wyniku ekonomicznego budżetu państwa jako \% PKB była w pozostałych krajach UE większa niż w krajach Europy Środkowej i Wschodniej. W większości pozostałych krajów UE spadkowi realnego PKB towarzyszył bowiem spadek nominalnego PKB (w większości krajów Europy Środkowej i Wschodniej nominalny PKB wzrósł w analizowanym okresie, a były też kraje gdzie wzrósł zarówno realny, jak i nominalny PKB). Oznaczało to, że nawet gdyby kraje te zachowały nominalne wydatki budżetowe na poziomie z 2007 roku, to i tak udział wydatków budżetowych w PKB zmniejszyłby się i oddziaływałby na pogorszenie się wyniku budżetu państwa.

Spośród krajów Europy Środkowej i Wschodniej jedynie w dwóch - Polsce i Bułgarii - w latach 2008-2009 nastąpił znaczny spadek dochodów budżetowych wyrażonych w PKB. Polska i Bułgaria są zatem jedynymi krajami, w których spadek udziału dochodów budżetowych w PKB był wyłączną (Bułgaria), bądź istotną (Polska) przyczyną wzrostu deficytu ekonomicznego budżetu państwa. W obu tych krajach znaczny spadek udziału dochodów budżetowych w PKB w latach 2008-2009 nie był związany z bieżącym tempem wzrostu gospodarczego (zresztą w obu krajach w badanym okresie wzrósł zarówno realny jak i nominalny PKB), lecz z bieżącą polityką budżetową (obniżanie stawek niektórych podatków). $Z$ kolei spośród pozostałych krajów UE tylko w przypadku Hiszpanii i Cypru spadek dochodów budżetowych wyrażonych w PKB był równie istotną przyczyną pogorszenia się wyniku ekonomicznego budżetu państwa jako \% PKB jak wzrost udziału wydatków budżetowych w PKB. W innych krajach, mimo spadku realnego i nominalnego PKB, udział dochodów budżetowych w PKB wzrastał albo spadał w na tyle małym stopniu, że jego zmiana $w$ niewielkim stopniu odpowiadała za pogorszenie wyniku ekonomicznego.

W latach 2008-2009 średni udział dochodów budżetowych w PKB w analizowanych krajach Europy Środkowej i Wschodniej nie zmienił się, a średni udział wydatków budżetowych w PKB wzrósł o 5,0 pkt. proc. W pozostałych krajach UE udział dochodów budżetowych w PKB był w 2009 roku o 0,5 pkt. proc. mniejszy, 
a udział wydatków budżetowych o 5,6 pkt. proc. większy (w porównaniu z bazowym rokiem 2007). Te dane pokazują, gdzie należy upatrywać przyczyny kryzysu finansów publicznych w obu grupach krajów w analizowanym okresie.

Czwarty wniosek płynący z analizy jest taki, że w pozostałych krajach UE średni wzrost długu publicznego jako \% PKB był w latach 2008-2009 większy od średniego wzrostu długu publicznego w krajach Europy Środkowej i Wschodniej. W przypadku pozostałych krajów UE dług publiczny wyrażony w \% PKB był na koniec 2009 roku średnio o 12,9 pkt. proc. wyższy niż na koniec 2007 roku, a w przypadku krajów Europy Środkowej i Wschodniej - o 9,4 pkt. proc. wyższy.

Przypomnijmy jeszcze, jaki był stan budżetu państwa w 2009 roku w analizowanych krajach Europy Środkowej i Wschodniej oraz w pozostałych krajach Unii Europejskiej. Wśród pierwszej grupy krajów jedynie w Estonii budżet państwa zamykał się niskim deficytem ekonomicznym jako \% PKB (tzn. niższym od kryterium z Maastricht w tym zakresie). Dobry wynik budżetu państwa w 2009 roku to efekt tego, że w 2007 roku Estonia notowała najlepszy spośród analizowanych krajów wynik budżetu państwa (nadwyżka na poziomie 2,6\% PKB), a w latach 2008-2009 należała do państw, w których skala pogorszenia się wyniku ekonomicznego była najniższa. Trzeba jednak przypomnieć, że w Estonii postanowiono zamienić część wzrostu deficytu ekonomicznego budżetu państwa na inne niekorzystne dla gospodarki zjawisko, a mianowicie wzrost obciążeń podatkowych. Pozostałe kraje notowały w 2009 roku wysoki deficyt ekonomiczny jako \% PKB (tzn. przekraczający 3,0\% PKB). Przy czym najwyższym deficytem ekonomicznym - mieszczącym się w przedziale 7,0-9,0 \% PKB - odznaczały się Litwa, Łotwa, Rumunia i Polska.

Średni deficyt ekonomiczny jako \% PKB wyniósł w 2009 roku w krajach Europy Środkowej i Wschodniej 6,11\% PKB. Dla porównania w 2009 roku w pozostałych krajach UE średni deficyt ekonomiczny jako \% PKB był wyższy i wyniósł 6,28\% PKB. A zatem w pozostałych krajach UE w latach 2008-2009 nastąpiło większe średnie pogorszenie się wyniku ekonomicznego budżetu państwa jako \% PKB i w efekcie kraje te odznaczały się w 2009 roku większym średnim deficytem ekonomicznym wyrażonym w \% PKB. W 2009 roku w pozostałych krajach UE wyższe były też średnie dochody budżetowe jako \% PKB (wyniosły 45,0\% PKB) oraz średnie wydatki budżetowe jako \% PKB (wyniosły 50,8\% PKB). W krajach Europy Środkowej i Wschodniej średnie dochody budżetowe w 2009 roku wyniosły 38,3\% PKB, a średnie wydatki budżetowe 44,4\% PKB.

Mimo znacznego pogorszenia się wyniku ekonomicznego budżetu państwa jako \% PKB w latach 2008-2009, w większości tych krajów na koniec 2009 roku nadal notowano niski poziom długu publicznego wyrażonego w \% PKB (tzn. znacznie niższy od 60,0\% PKB). Na koniec 2009 roku średni dług publiczny w analizowanych 
krajach Europy Środkowej i Wschodniej wynosił 34,7\% PKB. Wysoki dług publiczny notowano na koniec 2009 roku jedynie na Węgrzech (78,3\% PKB) i w Polsce $(51,0 \%$ PKB). Na koniec 2009 roku w krajach Europy Środkowej i Wschodniej średni dług publiczny był znacznie niższy niż w pozostałych krajach Unii Europejskiej (odpowiednio 34,7\% i 66,8\%). Aż w 11 z pozostałych krajów UE dług publiczny przekraczał $60,0 \%$ PKB (przy czym we Włoszech, Belgii, Grecji, Francji, Niemczech i Portugalii zbliżał się lub przekraczał 75,0\% PKB) . Dług publiczny poniżej 60,0\% PKB notowano jedynie w Danii, Finlandii, Szwecji, Hiszpanii, Luksemburgu i na Cyprze. Na progu światowego kryzysu gospodarczego, dzięki niskiemu poziomowi długu publicznego jako \% PKB, kraje Europy Środkowej i Wschodniej miały większą przestrzeń dla bezpiecznego dla stanu finansów publicznych i gospodarki wzrostu deficytu ekonomicznego budżetu państwa niż pozostałe kraje UE. Dlatego pogorszenie się wyniku ekonomicznego budżetu państwa w latach 2008-2009 nie doprowadziło w większości krajów Europy Środkowej i Wschodniej do tak dramatycznej sytuacji finansów publicznych, jak miało to miejsce w większości pozostałych krajów UE.

\section{Analiza zmian deficytu ekonomicznego budżetu państwa oraz długu publicznego w państwach Unii Europejskiej w 2010 roku}

Analizy dokonano oddzielnie dla krajów Europy Środkowej i Wschodniej należących do Unii Europejskiej oraz pozostałych krajów UE.

W 2010 roku w grupie krajów Europy Środkowej i Wschodniej należących do Unii Europejskiej tylko w Rumunii i na Łotwie odnotowano recesję gospodarczą, czyli spadek realnego PKB. Należy jednak podkreślić, iż w Rumunii w 2010 roku, mimo zmniejszenia się realnego PKB, nastąpił wzrost nominalnego PKB (negatywny wpływ spadku realnego PKB na poziom nominalnego PKB został bowiem z nadwyżką zneutralizowany przez wpływ procesów inflacyjnych). Na Łotwie z kolei spadkowi realnego PKB towarzyszył spadek nominalnego PKB. W pozostałych, spośród analizowanych, krajach Europy Środkowej i Wschodniej w 2010 roku nastąpił wzrost zarówno nominalnego PKB, jak i realnego PKB. Dla porównania w 2009 roku w tej grupie krajów realny PKB wzrósł jedynie w Polsce, a w trzech krajach (Estonia, Litwa, Łotwa) spadkowi realnego PKB towarzyszył spadek nominalnego PKB.

W 2010 roku największą dynamiką wzrostu realnego PKB oraz nominalnego PKB odznaczały się Słowacja i Polska. W krajach tych zmienność PKB najbardziej sprzyjała zatem poprawie wyniku ekonomicznego budżetu państwa jako \% PKB. 
Tabela 1. Tempo zmian nominalnego $\mathrm{PKB}_{\mathrm{CR}}$ oraz tempo zmian realnego $\mathrm{PKB}_{\mathrm{CR}}$ w 2010 roku w krajach Europy Środkowej i Wschodniej (w \%)

\begin{tabular}{|l|c|c|}
\hline \multicolumn{1}{|c|}{ Kraj } & Tempo zmian nominalnego PKB & Tempo zmian realnego PKB \\
\hline Bułgaria & 3,2 & 0,2 \\
\hline Czechy & 1,2 & 2,3 \\
\hline Estonia & 4,3 & 2,3 \\
\hline Łotwa & $-2,6$ & $-0,3$ \\
\hline Litwa & 3,4 & 1,3 \\
\hline Węgry & 4,1 & 1,2 \\
\hline Polska & 5,4 & 3,8 \\
\hline Rumunia & 3,1 & $-1,3$ \\
\hline Stowenia & 2,0 & 1,4 \\
\hline Stowacja & 4,4 & 4,0 \\
\hline
\end{tabular}

Źródło: opracowanie własne na podstawie danych Eurostatu.

W latach 2008-2009 nastąpiło pogorszenie się wyniku ekonomicznego budżetu państwa jako \% PKB we wszystkich, oprócz Węgier, krajach Europy Środkowej i Wschodniej należących do UE. Tymczasem w 2010 roku większość z tej grupy krajów zeszła ze ścieżki pogłębiania się deficytu ekonomicznego budżetu państwa. Aż w ośmiu krajach wynik ekonomiczny budżetu państwa polepszył się, a w przypadku Słowacji utrzymał się na poziomie z 2009 roku. W największym stopniu deficyt ekonomiczny budżetu państwa zmniejszył się na Litwie, w Rumunii i na Łotwie (o 2,0-2,4 pkt. proc.).

Należy teraz przyjrzeć się przyczynom redukcji deficytu budżetu państwa w krajach, w których ona nastąpiła. Aż w czterech z nich, tzn. w Bułgarii, Estonii, na Litwie i na Węgrzech, za zmniejszenie się deficytu ekonomicznego budżetu państwa odpowiadał wyłącznie spadek udziału wydatków budżetowych w PKB (w krajach tych bowiem zmniejszyły się dochody budżetowe jako \% PKB). W trzech spośród tych krajów (wyjątek stanowiły Węgry) do zmniejszenia się wydatków budżetowych jako \% PKB przyczynił się nie tylko wzrost nominalnego PKB, ale co istotne także spadek nominalnych wydatków budżetowych. W okresie 2008-2009 roczne nominalne wydatki budżetowe wzrosły w Bułgarii, Estonii i na Litwie o 14-16\%. W 2010 roku polityce budżetowej tych krajów udało się doprowadzić do spadku tych wydatków. 
Tabela 2. Wynik ekonomiczny budżetu państwa jako \% $\mathrm{PKB}_{\mathrm{CR}}$ w krajach Europy Środkowej i Wschodniej w latach 2009-2010

\begin{tabular}{|l|c|c|}
\hline \multicolumn{1}{|c|}{ Kraj } & 2009 & 2010 \\
\hline Bułgaria & $-4,7$ & $-3,2$ \\
\hline Czechy & $-5,8$ & $-4,7$ \\
\hline Estonia & $-1,8$ & 0,1 \\
\hline Łotwa & $-9,6$ & $-7,6$ \\
\hline Litwa & $-9,5$ & $-7,1$ \\
\hline Węgry & $-4,5$ & $-4,3$ \\
\hline Polska & $-7,3$ & $-7,9$ \\
\hline Rumunia & $-8,5$ & $-6,4$ \\
\hline Słowenia & $-6,0$ & $-5,6$ \\
\hline Słowacja & $-7,9$ & $-7,9$ \\
\hline
\end{tabular}

Źródło: opracowanie własne na podstawie danych Eurostatu.

$\mathrm{Na}$ Węgrzech natomiast nominalne wydatki budżetowe wprawdzie minimalnie wzrosły, ale dynamika tego wzrostu była niższa od dynamiki wzrostu nominalnego PKB.

Spadek udziału wydatków budżetu państwa w PKB był także główną determinantą poprawy wyniku ekonomicznego budżetu państwa w Czechach i na Łotwie. W krajach tych jednak za pewną część tej poprawy odpowiadał wzrost dochodów budżetowych jako \% PKB. W Czechach i na Łotwie również udało się w 2010 roku zmniejszyć nominalne wydatki budżetowe. Warto podkreślić, że spadek udziału wydatków budżetowych jako \% PKB na Łotwie dokonał się w warunkach spadku realnego PKB i nominalnego PKB.

Rumunia i Słowenia tworzyły w analizowanym roku tę grupę krajów, w których udało się utrzymać udział wydatków budżetowych w PKB na poziomie z 2009 roku i w których jedynym źródłem zmniejszenia deficytu ekonomicznego jako \% PKB był wzrost dochodów budżetowych jako \% PKB.

Jak wspomniano powyżej, Polska i Słowacja odznaczały się w 2010 roku najwyższą dynamiką wzrostu realnego PKB i nominalnego PKB. Kraje te miały zatem najkorzystniejsze warunki do zmniejszenia deficytu ekonomicznego budżetu państwa jako \% PKB. Miały one bowiem największą przestrzeń dla wzrostu nominalnych wydatków budżetowych, który nie prowadziłby do wzrostu udziału tych wydatków w PKB. Kraje te nie wykorzystały jednak wysokiego tempa wzrostu PKB do redukcji deficytu budżetu państwa jako \% PKB. Szczególnie dotyczy to Polski, gdzie w 2010 roku zanotowano najwyższy spośród krajów Europy Środkowej i Wschodniej należących do UE wzrost nominalnego PKB. Niestety, z drugiej strony Polska odznaczała 
się najwyższym tempem wzrostu nominalnych wydatków budżetowych. Wzrost nominalnych wydatków budżetowych był w Polsce w 2010 roku jedynym źródłem wzrostu deficytu budżetowego jako \% PKB (nastąpił bowiem wzrost udziału dochodów budżetowych w PKB). Pogorszenie się wyniku ekonomicznego budżetu państwa w 2010 roku spowodowało, że Polska odznaczała się w tym roku największym deficytem ekonomicznym budżetu państwa jako \% PKB spośród wszystkich krajów Europy Środkowej i Wschodniej. W 2010 roku w tej grupie krajów najlepszy wynik budżetu państwa zanotowano w Estonii, gdzie budżet zamknął się nadwyżką ekonomiczną na poziomie $0,1 \%$ PKB. W żadnym innym kraju deficyt nie był niższy niż 3,0\% PKB.

Tabela 3. Dochody budżetu państwa jako \% $\mathrm{PKB}_{\mathrm{CR}} \mathrm{w}$ krajach

Europy Środkowej i Wschodniej w latach 2009-2010

\begin{tabular}{|l|l|l|}
\hline \multicolumn{1}{|c|}{ Kraj } & 2009 & 2010 \\
\hline Butgaria & 36,0 & 34,5 \\
\hline Czechy & 40,1 & 40,5 \\
\hline Estonia & 43,4 & 40,1 \\
\hline Łotwa & 34,6 & 35,2 \\
\hline Litwa & 34,5 & 34,2 \\
\hline Węgry & 46,1 & 44,6 \\
\hline Polska & 37,2 & 37,8 \\
\hline Rumunia & 32,1 & 34,3 \\
\hline Stowenia & 43,1 & 43,4 \\
\hline Stowacja & 33,6 & 33,1 \\
\hline
\end{tabular}

Źródło: opracowanie własne na podstawie danych Eurostatu.

Tabela 4. Wydatki budżetu państwa jako \% $\mathrm{PKB}_{\mathrm{CR}}$ w krajach Europy Środkowej i Wschodniej w latach 2009-2010

\begin{tabular}{|l|c|c|}
\hline \multicolumn{1}{|c|}{ Kraj } & 2009 & 2010 \\
\hline Bułgaria & 40,7 & 37,7 \\
\hline Czechy & 45,9 & 45,2 \\
\hline Estonia & 45,2 & 40,0 \\
\hline Łotwa & 44,2 & 42,9 \\
\hline Litwa & 44,0 & 41,3 \\
\hline Węgry & 50,5 & 48,9 \\
\hline Polska & 44,5 & 45,7 \\
\hline Rumunia & 40,6 & 40,8 \\
\hline Słowenia & 49,0 & 49,0 \\
\hline Stowacja & 41,5 & 41,0 \\
\hline
\end{tabular}

Źródło: opracowanie własne na podstawie danych Eurostatu. 
Tabela 5. Tempo zmian rocznych nominalnych dochodów budżetu państwa oraz tempo zmian rocznych nominalnych wydatków budżetu państwa w krajach Europy Środkowej i Wschodniej w 2010 roku (w porównaniu $\mathrm{z}$ rokiem $2009, \mathrm{w} \%$ )

\begin{tabular}{|l|c|c|}
\hline \multicolumn{1}{|c|}{ Kraj } & $\begin{array}{c}\text { Tempo zmian dochodów } \\
\text { budżetu państwa }\end{array}$ & $\begin{array}{c}\text { Tempo zmian wydatków } \\
\text { budżetu państwa }\end{array}$ \\
\hline Bułgaria & $-1,2$ & $-4,3$ \\
\hline Czechy & 2,3 & $-0,5$ \\
\hline Estonia & $-3,3$ & $-7,9$ \\
\hline Łotwa & $-0,9$ & $-5,5$ \\
\hline Litwa & 2,5 & $-3,0$ \\
\hline Węgry & 0,8 & 0,6 \\
\hline Polska & 7,3 & 8,2 \\
\hline Rumunia & 10,5 & 3,7 \\
\hline Słowenia & 2,6 & 1,7 \\
\hline Słowacja & 2,8 & 3,1 \\
\hline
\end{tabular}

Źródło: opracowanie własne na podstawie danych Eurostatu.

Dzięki uzyskanej nadwyżce budżetowej Estonia była w 2010 roku jedynym spośród krajów Europy Środkowej i Wschodniej państwem, w którym zmniejszył się dług publiczny jako \% PKB. W tej grupie krajów największy wzrost długu publicznego jako \% PKB zanotowano na Litwie, na Łotwie oraz w Rumunii. Mimo że w krajach tych odnotowano w 2010 roku największą skalę redukcji deficytu ekonomicznego jako \% PKB, to deficyt ten nadal pozostawał na wysokim poziomie. $\mathrm{Na}$ koniec 2010 roku kraje Europy Środkowej i Wschodniej nadal odznaczały się relatywnie niskim poziomem długu publicznego jako \% PKB. Najwyższym długiem publicznym na koniec rozpatrywanego roku odznaczały się Węgry, gdzie przekroczył on $80,0 \%$ PKB. W żadnym z pozostałych krajów tej grupy dług publiczny nie przekroczył 60,0\% PKB. W większości analizowanych krajów Europy Środkowej i Wschodniej (wyjątek stanowią Węgry i Polska) nadal zatem istnieje znaczna przestrzeń dla bezpiecznego dla stanu finansów publicznych utrzymywania się wysokiego deficytu ekonomicznego budżetu państwa.

Przechodząc do analizy stanu finansów w 2010 roku w pozostałych krajach Unii Europejskiej, należy stwierdzić, że w zdecydowanej większości tych krajów zanotowano wzrost zarówno nominalnego $\mathrm{PKB}$, jak i realnego $\mathrm{PKB}$, a zatem istniała przestrzeń dla takiego wzrostu wydatków budżetu, który nie prowadzi do wzrostu deficytu ekonomicznego budżetu państwa wyrażonego jako \% PKB. W 2010 roku tylko w Grecji i Irlandii doszło do zmniejszenia się zarówno nominalnego PKB, jak i realnego PKB. W Hiszpanii wprawdzie nastąpił spadek realnego PKB, ale towarzyszył mu wzrost nominalnego PKB. 
Tabela 6. Dług publiczny jako \% $\mathrm{PKB}_{\mathrm{CR}} \mathrm{w}$ krajach Europy Środkowej i Wschodniej na koniec lat 2009-2010

\begin{tabular}{|l|c|c|}
\hline \multicolumn{1}{|c|}{ Kraj } & 2009 & 2010 \\
\hline Bułgaria & 14,6 & 16,2 \\
\hline Czechy & 35,3 & 38,5 \\
\hline Estonia & 7,2 & 6,6 \\
\hline Łotwa & 36,7 & 44,7 \\
\hline Litwa & 29,5 & 38,2 \\
\hline Węgry & 78,4 & 80,2 \\
\hline Polska & 50,9 & 55,0 \\
\hline Rumunia & 23,6 & 30,8 \\
\hline Słowenia & 35,2 & 38,0 \\
\hline Słowacja & 35,4 & 41,0 \\
\hline
\end{tabular}

Źródło: opracowanie własne na podstawie danych Eurostatu.

Tabela 7. Tempo zmian nominalnego $\mathrm{PKB}_{\mathrm{CR}}$ oraz tempo zmian realnego $\mathrm{PKB}_{\mathrm{CR}}$ w 2010 roku w pozostałych krajach Unii Europejskiej (w \%)

\begin{tabular}{|l|c|c|}
\hline \multicolumn{1}{|c|}{ Kraj } & Tempo zmian nominalnego PKB & Tempo zmian realnego PKB \\
\hline Austria & 3,5 & 2,3 \\
\hline Belgia & 3,9 & 2,3 \\
\hline Luksemburg & 9,2 & 3,5 \\
\hline Dania & 5,4 & 1,7 \\
\hline Malta & 6,8 & 2,7 \\
\hline Niemcy & 4,3 & 3,7 \\
\hline Holandia & 3,4 & 1,7 \\
\hline Grecja & $-2,0$ & $-4,5$ \\
\hline Hiszpania & 0,8 & $-0,1$ \\
\hline Francja & 2,1 & 1,5 \\
\hline Włochy & 1,9 & 1,3 \\
\hline Cypr & 3,6 & 1,0 \\
\hline Finlandia & 5,3 & 3,6 \\
\hline Szwecja & 6,9 & 5,6 \\
\hline Portugalia & 2,3 & 1,3 \\
\hline Wielka Brytania & 4,2 & 1,4 \\
\hline Irlandia & $-3,6$ & $-0,4$ \\
\hline
\end{tabular}

Źródło: opracowanie własne na podstawie danych Eurostatu. 
Tabela 8. Wynik ekonomiczny budżetu państwa jako \% $\mathrm{PKB}_{\mathrm{CR}}$ w pozostałych krajach Unii Europejskiej w latach 2009-2010

\begin{tabular}{|l|c|c|}
\hline \multicolumn{1}{|c|}{ Kraj } & 2009 & 2010 \\
\hline Austria & $-4,1$ & $-4,6$ \\
\hline Belgia & $-6,0$ & $-4,2$ \\
\hline Luksemburg & $-0,9$ & $-1,7$ \\
\hline Dania & $-2,8$ & $-2,9$ \\
\hline Malta & $-3,7$ & $-3,6$ \\
\hline Niemcy & $-3,0$ & $-3,3$ \\
\hline Holandia & $-5,5$ & $-5,3$ \\
\hline Grecja & $-15,6$ & $-10,4$ \\
\hline Hiszpania & $-11,1$ & $-9,2$ \\
\hline Francja & $-7,5$ & $-7,0$ \\
\hline Wiochy & $-5,3$ & $-4,5$ \\
\hline Cypr & $-6,0$ & $-5,3$ \\
\hline Finlandia & $-2,9$ & $-2,8$ \\
\hline Szwecja & $-0,9$ & $-0,3$ \\
\hline Portugalia & $-10,1$ & $-9,2$ \\
\hline Wielka Brytania & $-11,2$ & $-10,2$ \\
\hline Irlandia & $-14,3$ & $-32,4$ \\
\hline
\end{tabular}

Źródło: opracowanie własne na podstawie danych Eurostatu.

W latach 2008-2009 we wszystkich pozostałych krajach UE nastąpiło pogorszenie się wyniku ekonomicznego budżetu państwa jako \% PKB. W 2010 roku tylko w 5 krajach z tej grupy (Niemcy, Dania, Austria, Irlandia, Luksemburg) zanotowano dalsze powiększanie się deficytu ekonomicznego budżetu państwa. Przy czym tylko w Irlandii skala tego pogorszenia była bardzo duża, w przypadku czterech pozostałych państw wyniosła od 0,1 do 0,8 pkt. proc.

Podobnie jak w grupie krajów Europy Środkowej i Wschodniej należących do UE, wśród pozostałych krajów UE w 2010 roku dominowały państwa, w których nastąpiła poprawa wyniku ekonomicznego budżetu państwa jako \% PKB. W największym stopniu deficyt ekonomiczny budżetu państwa zmniejszył się w Grecji, gdzie zredukowano go o 5,2 pkt. proc. W innych spośród krajów, w których zmniejszono deficyt budżetowy, skala jego redukcji wyniosła od 0,1 do 1,9 pkt. proc. Teraz należy zidentyfikować przyczyny zmiany deficytu ekonomicznego budżetu państwa w 2010 roku, zarówno w tych krajach, w których nastąpił jego wzrost, jak i w tych, w których nastąpiła jego redukcja.

Jeżeli chodzi o kraje, które w 2010 roku utrzymywały się na ścieżce wzrostu deficytu budżetowego jako \% PKB, to tylko w Irlandii za wzrost ten w pełni odpowiada 
wzrost udziału wydatków budżetowych w PKB (udział dochodów budżetowych w PKB zwiększył się bowiem w 2010 roku). Wzrost wydatków budżetowych jako \% PKB był z kolei spowodowany w Irlandii przede wszystkim silnym wzrostem nominalnych wydatków budżetowych, a tylko w niewielkim stopniu spadkiem nominalnego PKB. W innych krajach wzrost deficytu budżetowego jako \% PKB był spowodowany wyłącznie spadkiem udziału dochodów budżetowych w PKB. W państwach tych bowiem tempo wzrostu nominalnych wydatków budżetowych było równe lub mniejsze od tempa wzrostu nominalnego PKB.

W 12 krajach spośród grupy pozostałych państw UE w 2010 roku nastąpiło polepszenie wyniku ekonomicznego budżetu państwa jako \% PKB. W zdecydowanej większości tych krajów jedynym lub istotnym źródłem zmniejszenia deficytu ekonomicznego budżetu państwa było zmniejszenie udziału wydatków budżetowych w PKB. Redukcję wydatków budżetowych jako \% PKB osiągnięto dzięki znacznemu zmniejszeniu (w porównaniu $z$ latami 2008-2009) tempa wzrostu nominalnych wydatków budżetowych. W niektórych krajach (Hiszpania, Włochy, Grecja) w 2010 roku odnotowano nawet spadek nominalnych wydatków budżetowych. Ograniczenie dynamiki wzrostu nominalnych wydatków budżetu państwa spowodowało, że tempo wzrostu tych wydatków było niższe od tempa wzrostu nominalnego PKB, co zaowocowało właśnie spadkiem udziału wydatków budżetowych w PKB.

Do krajów, w których redukcja deficytu ekonomicznego budżetu państwa jako \% PKB była w 2010 roku spowodowana wyłącznie zmniejszeniem udziału wydatków budżetowych w PKB, należą Włochy, Szwecja, Holandia, Finlandia oraz Malta. W krajach tych dochody budżetowe jako \% PKB w 2010 roku zmniejszyły się lub nie uległy zmianie.

Redukcja wydatków budżetu państwa jako \% PKB była główną determinantą zmniejszenia deficytu ekonomicznego budżetu państwa także w Belgii, Grecji i Włoszech. W krajach tych jednak częściowo za poprawę wyniku budżetowego odpowiadał wzrost udziału dochodów budżetowych w PKB. Z kolei w przypadku Hiszpanii do ograniczenia deficytu budżetu państwa niemal w identycznym stopniu przyczyniły się spadek wydatków budżetowych jako \% PKB oraz wzrost udziału dochodów budżetowych w PKB.

Jedynie we Francji, Portugalii i na Cyprze deficyt ekonomiczny budżetu państwa jako \% PKB zmniejszył się w 2010 roku wyłącznie poprzez wzrost udziału dochodów budżetowych w PKB. We Francji wydatki budżetowe jako \% PKB nie zmieniły się, a w Portugali i na Cyprze wzrosły. 
Tabela 9. Dochody budżetu państwa jako \% $\mathrm{PKB}_{\mathrm{CR}}$

w pozostałych krajach Unii Europejskiej w latach 2009-2010

\begin{tabular}{|l|c|c|}
\hline \multicolumn{1}{|c|}{ Kraj } & 2009 & 2010 \\
\hline Austria & 48,8 & 48,3 \\
\hline Belgia & 48,1 & 48,9 \\
\hline Luksemburg & 41,3 & 39,5 \\
\hline Dania & 55,6 & 55,3 \\
\hline Malta & 39,5 & 38,7 \\
\hline Niemcy & 44,5 & 43,3 \\
\hline Holandia & 45,9 & 45,9 \\
\hline Grecja & 37,3 & 39,1 \\
\hline Hiszpania & 34,7 & 35,7 \\
\hline Francja & 48,7 & 49,2 \\
\hline Włochy & 46,5 & 46,6 \\
\hline Cypr & 39,8 & 41,3 \\
\hline Finlandia & 53,4 & 52,3 \\
\hline Szwecja & 54,2 & 52,7 \\
\hline Portugalia & 39,7 & 41,5 \\
\hline Wielka Brytania & 40,3 & 40,6 \\
\hline Irlandia & 33,9 & 34,6 \\
\hline
\end{tabular}

Źródło: opracowanie własne.

Tabela 10. Wydatki budżetu państwa jako $\% \mathrm{PKB}_{\mathrm{CR}} \mathrm{w}$ pozostałych krajach Unii Europejskiej w latach 2009-2010

\begin{tabular}{|l|c|c|}
\hline \multicolumn{1}{|c|}{ Kraj } & 2009 & 2010 \\
\hline Austria & 53,0 & 53,0 \\
\hline Belgia & 50,1 & 53,1 \\
\hline Luksemburg & 42,2 & 41,2 \\
\hline Dania & 58,4 & 58,2 \\
\hline Malta & 43,2 & 42,3 \\
\hline Niemcy & 47,5 & 46,6 \\
\hline Holandia & 51,4 & 51,2 \\
\hline Grecja & 52,9 & 49,5 \\
\hline Hiszpania & 45,8 & 45,0 \\
\hline Francja & 56,2 & 56,2 \\
\hline Włochy & 51,8 & 50,5 \\
\hline Cypr & 45,8 & 46,6 \\
\hline Finlandia & 56,3 & 55,1 \\
\hline Szwecja & 55,2 & 53,0 \\
\hline Portugalia & 49,8 & 50,7 \\
\hline
\end{tabular}




\begin{tabular}{|l|c|c|}
\hline \multicolumn{1}{|c|}{ Kraj } & 2009 & 2010 \\
\hline Wielka Brytania & 51,4 & 50,9 \\
\hline Irlandia & 48,2 & 67,0 \\
\hline
\end{tabular}

Źródło: opracowanie własne.

Tabela 11. Tempo zmian rocznych nominalnych dochodów budżetu państwa oraz tempo zmian rocznych nominalnych wydatków budżetu państwa w pozostałych krajach Unii Europejskiej w 2010 roku (w porównaniu $\mathrm{z}$ rokiem $2009, \mathrm{w} \%$ )

\begin{tabular}{|l|c|c|}
\hline \multicolumn{1}{|c|}{ Kraj } & $\begin{array}{c}\text { Tempo zmian dochodów } \\
\text { budżetu państwa }\end{array}$ & $\begin{array}{c}\text { Tempo zmian wydatków } \\
\text { budżetu państwa }\end{array}$ \\
\hline Austria & 2,5 & 3,5 \\
\hline Belgia & 5,5 & 1,9 \\
\hline Luksemburg & 4,5 & 6,8 \\
\hline Dania & 4,9 & 5,1 \\
\hline Malta & 4,8 & 4,4 \\
\hline Niemcy & 1,5 & 2,2 \\
\hline Holandia & 3,5 & 3,1 \\
\hline Grecja & 2,6 & $-8,3$ \\
\hline Hiszpania & 4,1 & $-1,0$ \\
\hline Francja & 3,1 & 2,1 \\
\hline Włochy & 0,9 & $-0,6$ \\
\hline Cypr & 7,5 & 3,8 \\
\hline Finlandia & 3,3 & 3,1 \\
\hline Szwecja & 3,9 & 2,8 \\
\hline Portugalia & 7,0 & 4,2 \\
\hline Wielka Brytania & 5,2 & 3,0 \\
\hline Irlandia & $-1,5$ & 34,2 \\
\hline
\end{tabular}

Źródło: opracowanie własne.

Mimo że 2010 rok przyniósł poprawę wyniku budżetu państwa w większości z pozostałych krajów UE, to $\mathrm{w}$ wielu z nich deficyt ekonomiczny budżetu państwa jako \% PKB nadal pozostawał na wysokim poziomie, co w konsekwencji prowadziło do dalszego istotnego powiększania się długu publicznego wyrażonego w \% PKB.

W 2010 roku dług publiczny jako \% PKB w największym stopniu zwiększył się w Grecji (wzrósł o 15,7 pkt. proc.). W Niemczech, Portugalii, Wielkiej Brytanii i Irlandii dług publiczny w analizowanym roku wzrósł od 9,7 do 11,4 pkt. proc. W Hiszpanii dług publiczny powiększył się o 6,8 pkt. proc. W przypadku pozostałych krajów skala wzrostu długu publicznego kształtowała się w przedziale od 0,4 do 4,6 pkt. proc. Jedynym krajem spośród tej grupy, w którym dług publiczny w 2010 roku zmniejszył się, była Szwecja. 
Tabela 12. Dług publiczny jako \% $\mathrm{PKB}_{\mathrm{CR}}$ w pozostałych krajach Unii Europejskiej na koniec lat 2009-2010

\begin{tabular}{|l|c|c|}
\hline \multicolumn{1}{|c|}{ Kraj } & 2009 & 2010 \\
\hline Austria & 69,6 & 72,3 \\
\hline Belgia & 96,2 & 96,8 \\
\hline Luksemburg & 14,6 & 18,4 \\
\hline Dania & 41,8 & 43,6 \\
\hline Malta & 67,6 & 68,0 \\
\hline Niemcy & 73,5 & 83,2 \\
\hline Holandia & 60,8 & 62,7 \\
\hline Grecja & 127,1 & 142,8 \\
\hline Hiszpania & 53,3 & 60,1 \\
\hline Francja & 78,3 & 81,7 \\
\hline Włochy & 116,1 & 119,0 \\
\hline Cypr & 58,0 & 60,8 \\
\hline Finlandia & 43,8 & 48,4 \\
\hline Szwecja & 42,8 & 39,8 \\
\hline Portugalia & 83,0 & 93,0 \\
\hline Wielka Brytania & 69,6 & 80,0 \\
\hline Irlandia & 65,6 & 96,2 \\
\hline
\end{tabular}

Źródło: opracowanie własne.

Porównując skalę i determinanty zmian deficytu ekonomicznego budżetu państwa i długu publicznego w 2010 roku w krajach Europy Środkowej i Wschodniej należących do UE oraz w pozostałych krajach UE, dochodzimy do następujących wniosków (uwaga: na potrzeby tego porównania z grupy pozostałych krajów UE usunięto Irlandię, która w 2010 roku była jedynym krajem, w którym deficyt ekonomiczny budżetu państwa oraz udział wydatków budżetowych w PKB wzrosły $\mathrm{w}$ stopniu drastycznym, niereprezentatywnym dla innych krajów grupy):

1) Średnia skala poprawy wyniku ekonomicznego budżetu państwa jako \% PKB była większa w krajach Europy Środkowej i Wschodniej niż w pozostałych krajach UE. W pierwszej grupie krajów wynik ekonomiczny poprawił się średnio o 1,1 pkt. proc., a w drugiej o 0,75 pkt. proc.

2) Zarówno w większości krajów Europy Środkowej i Wschodniej, jak i w większości pozostałych krajów UE jedyną bądź główną determinantą redukcji deficytu ekonomicznego budżetu państwa jako \% PKB był spadek wydatków budżetowych wyrażonych w \% PKB. Zmniejszenie udziału wydatków budżetowych w PKB było $\mathrm{z}$ kolei efektem ograniczenia $\mathrm{w}$ ramach polityki budżetowej tempa wzrostu nominalnych wydatków budżetowych. W krajach Europy Środkowej i Wschodniej 
w 2010 roku nominalne wydatki budżetowe nawet średnio zmniejszyły się o 0,4\%, podczas gdy w 2009 roku średnio wzrosły o $16,1 \%$. W pozostałych krajach UE średnie tempo wzrostu nominalnych wydatków budżetu państwa zmniejszyło się z 12,4\% w 2009 roku do 2,2\% w 2010 roku. W obydwu grupach krajów do spadku udziału wydatków budżetowych w PKB przyczynił się także wzrost nominalnego PKB (w krajach Europy Środkowej i Wschodniej wzrósł średnio o 2,9\%, a w pozostałych krajach UE o 3,4\%). Należy jednak wyraźnie podkreślić, że gdyby w obydwu grupach krajów utrzymano dynamikę wzrostu nominalnych wydatków budżetowych z 2009 roku, nastąpiłby wzrost wydatków budżetowych jako \% PKB, mimo wzrostu nominalnego PKB.

3) W pozostałych krajach UE średni wzrost długu publicznego jako \% PKB był większy od średniego wzrostu długu publicznego w krajach Europy Środkowej i Wschodniej. W przypadku pozostałych krajów UE dług publiczny wyrażony jako \% PKB był na koniec 2010 roku o 4,65 pkt. proc. wyższy niż na koniec 2009 roku, a w przypadku krajów Europy Środkowej i Wschodniej - o 4,14 pkt. proc. wyższy.

$\mathrm{W}$ tym miejscu warto jeszcze raz przyjrzeć się skali i przyczynom wzrostu deficytu ekonomicznego budżetu państwa jako \% PKB w 2010 roku w Polsce.

W analizowanym roku Polska odznaczała się relatywnie wysokim tempem wzrostu realnego PKB oraz relatywnie wysokim tempem wzrostu nominalnego PKB. Wśród krajów UE wyższe niż w Polsce tempo wzrostu realnego PKB zanotowano jedynie w Szwecji i na Słowacji, a wyższe tempo wzrostu nominalnego PKB w Szwecji, Luksemburgu i na Malcie. Mimo to tylko w Irlandii zanotowano w 2010 roku wyższą niż w Polsce skalę wzrostu deficytu ekonomicznego budżetu państwa jako \% PKB. Było to efektem tego, że Polska nie ograniczyła (jak stało się to w innych państwach) tempa wzrostu nominalnych wydatków budżetowych (wzrosły w 2010 roku o 8,2\%). W UE tylko w Irlandii w omawianym roku mieliśmy do czynienia z wyższą dynamiką wzrostu nominalnych wydatków budżetowych. Konsekwencją wysokiego tempa wzrostu nominalnych wydatków budżetowych był znaczny wzrost (o 1,2 pkt. proc.) udziału wydatków budżetowych w PKB. W 2010 roku Polska zatem ponownie nie wykorzystała wzrostu nominalnego PKB i wzrostu realnego PKB dla redukcji deficytu ekonomicznego budżetu państwa (podobnie było w okresie 2008-2009).

\section{Podsumowanie}

Na koniec spróbujmy ocenić, jaki był w 2010 roku stan budżetu państwa w krajach Europy Środkowej i Wschodniej należących do UE oraz w pozostałych krajach 
UE. W pierwszej grupie krajów jedynie w Estonii budżet państwa zamknął się nadwyżką ekonomiczną. W pozostałych krajach zanotowano wysoki deficyt ekonomiczny jako \% PKB (tzn. przekraczający 3,0\% PKB, czyli kryterium z Maastricht $\mathrm{w}$ tym zakresie). Najwyższym deficytem ekonomicznym - mieszczącym się w przedziale 6,4-7,9\% PKB - odznaczały się Rumunia, Litwa, Łotwa, Słowacja i Polska. W grupie pozostałych krajów UE deficyt ekonomiczny budżetu państwa niższy niż 3,0\% PKB zanotowano w Finlandii, Szwecji, Danii i Luksemburgu. W 7 krajach budżet państwa zamknął się deficytem ekonomicznym mieszczącym się w przedziale od 3\% do 7\% PKB. Największym deficytem ekonomicznym budżetu państwa w tej grupie krajów odznaczały się Irlandia (32,4\% PKB), Wielka Brytania, Portugalia, Hiszpania i Grecja (w tych krajach deficyt mieścił się w przedziale od 9,2\% do 10,4\% PKB). W 2010 roku średni deficyt ekonomiczny budżetu państwa w krajach Europy Środkowej i Wschodniej wyniósł 4,67\% PKB i był niższy od przeciętnego deficytu ekonomicznego zanotowanego w pozostałych krajach UE (bez Irlandii), który ukształtował się na poziomie 5,28\% PKB.

O lepszym stanie finansów publicznych w krajach Europy Środkowej i Wschodniej świadczy jednak przede wszystkim znacznie niższy średni poziom długu publicznego jako \% PKB na koniec 2010 roku. W przypadku pozostałych krajów UE średni dług publiczny na koniec 2010 roku wyniósł 74,8\% PKB, a w przypadku krajów Europy Środkowej i Wschodniej - 38,9\% PKB. W grupie krajów Europy Środkowej i Wschodniej na koniec analizowanego roku tylko Węgry odznaczały się długiem publicznym przekraczającym 60,0\% PKB (a zatem kryterium $\mathrm{z}$ Maastricht $\mathrm{w}$ tym zakresie). Ponadto jeszcze tylko $\mathrm{w}$ Polsce dług publiczny osiągnął poziom 55,0\% PKB. W 8 pozostałych krajach tej grupy dług publiczny był niższy niż 45,0\% PKB. Dla porównania tylko w $4 \mathrm{z}$ grupy pozostałych krajów UE na koniec 2010 roku zanotowano dług publiczny niższy od 60,0\% PKB (były to Szwecja, Dania, Finlandia i Luksemburg). W 6 krajach dług publiczny na koniec 2010 roku mieścił się w przedziale od 60,0\% do 80,0\% PKB, a w 5 - od $80,0 \%$ do $100,0 \%$ PKB. Na koniec omawianego roku najwyższym długiem publicznym odznaczały się Grecja (142,8\% PKB) i Włochy (119,0\% PKB).

Wysoki poziom długu publicznego, jakim charakteryzuje się większość krajów z grupy pozostałych państw UE, sprawia, że redukcję deficytu ekonomicznego budżetu państwa, jaka nastąpiła w wielu krajach tej grupy w 2010 roku, należy ocenić jako zdecydowanie za płytką. Po jej dokonaniu się deficyt budżetowy nadal pozostał bowiem na wysokim poziomie. W większości tych państw praktycznie nie ma już przestrzeni dla zwiększania długu publicznego, a zatem nie ma przestrzeni dla wysokiego deficytu budżetu państwa. W grupie krajów Europy Środkowej i Wschodniej należących do UE w takiej sytuacji znajdują się jedynie Węgry, a zbliża się do 
niej Polska. Większość pozostałych krajów UE oraz niektóre kraje Europy Środkowej i Wschodniej muszą zatem natychmiast istotnie zmniejszyć rozmiar deficytu ekonomicznego budżetu państwa. Kraje, w których dług publiczny jest relatywnie niski, też nie powinny zwlekać z dalszym ograniczaniem deficytu budżetu państwa, ponieważ później będą musiały dokonywać tej redukcji pod wpływem czasu. Ponadto sam wysoki deficyt ekonomiczny ma negatywny wpływ na gospodarkę, w tym na tempo wzrostu gospodarczego. Jeżeli krajom UE nie uda się szybko wejść na ścieżkę niskiego deficytu ekonomicznego budżetu państwa, trafią na wiele lat na ścieżkę recesji gospodarczej.

\section{Determinants of changes in state budget deficit and debt in the European Union in 2010}

The article contains an analysis of the budget deficit variability and public debt variation in the EU in 2010.

Comparing the scale and economic determinants of changes in the state budget deficit and public debt in 2010 in the Central and Eastern European EU member states and in other EU countries we reach the following conclusions:

1) The average scale of the improvement of the economic result of the state budget as \% of GDP was higher in the Central and Eastern Europe countries comparing to other EU member states. In the first group of countries, economic results improved on average by 1.1 percentage points, and in the other by 0.75 percentage points.

2) In most Central and Eastern European countries, as well as in most other EU countries the decline in budgetary expenditure, expressed in\% of GDP was the only or major determinant of the reduction of the economic deficit of the state budget as \% of GDP. Reduction of public spending in GDP was in turn the result of reducing the fiscal growth of nominal spending. In the Central and Eastern European countries in 2010, the nominal budget spending, decreased on average by $0.4 \%$, while in 2009 increased on average by $16.1 \%$.

3) In the rest of the EU average increase in public debt as \% of GDP was higher than the average increase in public debt in the countries of Central and Eastern Europe. For the rest of the EU member states, public debt at the end of 2010 as $\%$ of GDP was by 4.65 percentage points higher than at the end of 2009 , and for the Central and Eastern European countries by 4.14 percentage points higher. 
At the end of 2010 Central and Eastern European countries had significantly lower average level of public debt as \% of GDP in comparison with other EU members states (38.9\% of GDP and $74.8 \%$ of GDP). In most other EU countries there is virtually no limit for increasing the public debt, therefore there is no limit for a high budget deficit. Among Central and Eastern European EU member states only Hungary are in similar situation while Poland is close by. Therefore, most other EU countries and some countries of Central and Eastern Europe must immediately substantially reduce the scale of the economic deficit of the state budget. Countries where public debt is relatively low should not delay further restrictions of the state budget deficit as later on they will have to make this reduction under pressure of time. Above else, high economic deficit negatively impacts the economy, including economic growth.

If EU member states fail to implement quickly the low economic state budget deficit policy, they will plunge into economic recession that will last for many years.

\section{Les déterminants de l'évolution du déficit budgétaire de l'Etat et de la dette publique dans I'Union européenne en $\mathbf{2 0 1 0}$}

Larticle examine la variabilité du déficit budgétaire et celle de la dette publique dans l'UE en 2010.

En comparant l'ampleur et les déterminants économiques des changements dans le déficit budgétaire et dans la dette publique en 2010 dans les pays d'Europe centrale et orientale appartenant à l'UE et dans les autres pays de l'UE, nous arrivons aux conclusions suivantes:

1) La taille moyenne de l'amélioration des résultats économiques de budget de l'Etat en\% du PIB était plus élevée dans les pays d'Europe centrale et orientale que dans les autres pays européens. Dans le premier groupe de pays, les résultats économiques se sont améliorés en moyenne de 1,1 points de pourcentage, et dans l'autre de 0,75 points de pourcentage.

2) Dans la plupart des pays d'Europe centrale et orientale, ainsi que dans la plupart des autres pays de l'UE, la baisse des dépenses budgétaires, exprimée en $\%$ du PIB, était le seul déterminant ou le déterminant le plus important de la réduction du déficit du budget de l'Etat en\% du PIB. Cette diminution des dépenses publiques dans le PIB était à son tour le résultat de la réduction du taux de croissance des dépenses en valeur nominale dans le cadre de la politique budgétaire. Dans les pays d'Europe centrale et orientale en 2010 les dépenses budgétaires 
en valeur nominale ont diminué en moyenne de près de $0,4 \%$, tandis qu'elles avaient augmenté en moyenne de $16,1 \%$ en 2009.

3) Dans les autres pays de l'UE l'augmentation moyenne de la dette publique en $\%$ du PIB était plus élevée que celle de la dette publique dans les pays d'Europe centrale et orientale. Pour le reste des Etats membres de l'UE la dette publique en $\%$ du PIB était à la fin de 2010 en hausee de 4,65 points de pourcentage par rapport à la fin de 2009. Pour les pays d'Europe centrale et orientale la dette était de 4,14 points de pourcentage plus élevée.

A la fin de 2010 dans les pays d'Europe centrale et orientale la dette publique moyenne en $\%$ du PIB était beaucoup plus faible que dans les autres pays de l'UE (38,9\% du PIB et 74,8\% du PIB). Dans la plupart des autres pays européens il n’y a plus de possibilité pour augmenter la dette publique, et donc il n'y a pas de place pour un déficit budgétaire élevé. Parmi les pays d'Europe centrale et orientale appertenant à l'UE, c'est la Hongrie qui se trouve dans une telle situation et la Pologne se rapproche. La plupart des autres pays de l'UE et certains pays d'Europe centrale et orientale doivent donc immédiatement réduire considérablement la taille du déficit du budget de l'Etat. Les pays où la dette publique est relativement faible ne devraient pas retarder la réduction du déficit du budget de l'Etat, parce que plus tard ils seront obligés de démarrer une réduction sous la pression du temps. En outre, le déficit élevé a un impact négatif sur l'économie, y compris sur la croissance économique. Si les Etats membres de l'UE ne parviennent pas à mettre en oeuvre rapidement la politique visant à atteindre un déficit du budget bas, ils seront plongés dans la récession économique qui va durer pendant de nombreuses années. 